\title{
Age-dependent changes in ion channel mRNA expression in canine cardiac tissues
}

\author{
Mónika Gönczi ${ }^{1}$, Péter Birinyi ${ }^{1}$, Bernadett Balázs ${ }^{1}$, Norbert Szentandrássy ${ }^{1}$, Gábor Harmati ${ }^{1}$, \\ Zoltán Könczei ${ }^{2}$, László Csernoch ${ }^{1}$ and Péter P. Nánási ${ }^{1}$ \\ ${ }^{1}$ Department of Physiology, University of Debrecen, Debrecen, Hungary \\ ${ }^{2}$ K. Z. Veterinary Ambulance, Domb u. 16, Debrecen, Hungary
}

\begin{abstract}
The expression pattern of cardiac ion channels displays marked changes during ontogeny. This study was designed to follow the developmental changes in the expression of major ventricular and atrial ion channel proteins (including both pore forming and regulatory subunits) in canine cardiac tissues at the mRNA level using competitive reverse transcription polymerase chain reaction. Therefore, the corresponding mRNA levels were compared in myocardial tissues excised from embryonic (25-60 days of gestation) and adult (2-3 years old) canine hearts. Expression level of Kv4.3, Kv1.4, KChIP2, KvLQT1, and Cav3.2 mRNAs were higher in the adult than in the embryonic hearts, while expression of Nav1.5 and minK mRNAs were higher in the embryonic than in the adult myocardium. No change in Kir2.1, HERG, Kv1.5, and Cav1.2 mRNA was observed during ontogeny. Direction of the developmental change in the mRNA level, determined for any specific channel protein, was identical in the atrial and ventricular samples. The age-dependent increase observed in the expression of Kv4.3, Kv1.4, KChIP2, and KvLQT1 is congruent with the greater repolarization reserve of the adult myocardium, associated with higher densities of $\mathrm{I}_{\mathrm{to}}$ and $\mathrm{I}_{\mathrm{Ks}}$. The results indicate that age-dependent changes in the expression pattern of many ion channels are similar in canine and healthy human myocardium, therefore, canine cardiac muscle can be considered as a good model of studying developmental changes in the human heart.
\end{abstract}

Key words: Developmental changes — Dog heart — Ion channels - mRNA expression — Regional differences

\section{Introduction}

Configuration of the action potential, together with the density and properties of the underlying ion channels, is dramatically changing during the embryonic life. Most of these alterations extend into the early, and sometimes to the later postnatal period. The earliest relevant data were obtained from embryonic chick ventricular cells indicating that the density of some ion currents, like $\mathrm{I}_{\mathrm{Na}}$ and $\mathrm{I}_{\mathrm{K} 1}$ increased, while the density of others, such as $\mathrm{I}_{\mathrm{Ca}-\mathrm{L}}$, decreased with ontogeny in the prenatal period (Fujii et al. 1986; Sperelakis 1989; Tohse et al. 1992; Sada et al. 1995). Later these developmental studies were extended to cardiac preparations obtained from various mammalian species, including rats, mice, rabbits, and

Correspondence to: Péter P. Nánási, Department of Physiology, University of Debrecen, H-4012 Debrecen, P.O.Box 22, Hungary

E-mail: nanasi@phys.dote.hu guinea pigs. The results showed serious interspecies differences, suggesting that extrapolation of the ontogeny results from one species to another may be quite hazardous in the case of many ion currents. Regarding therapeutic relevance, human ontogeny data would be ideally required, however, we have only limited access to human embryonic heart tissues, in addition, these are almost exclusively atrial samples (Cohen and Lederer 1993; Mansourati and Le Grand 1993; Crumb et al. 1995; Roca et al. 1996). Data on embryonic human ventricular samples are restricted to action potential recordings (Jezek et al. 1982, 1984, 1985). This is the reason why we have chosen canine cardiac tissues (both ventricular and atrial ones) in the present developmental study, since canine heart is considered to be the best model of the human heart in terms of its electrophysiological properties, including action potential morphology and the set of the underlying ion currents (Szabó et al. 2005; Szentandrássy et al. 2005). In spite of the widespread interspecies differences found in the 
literature, our results obtained in developing canine cardiac tissues at the mRNA level are largely congruent with those of the corresponding human voltage clamp measurements, indicating that the density of $\mathrm{I}_{\mathrm{to}}$ is increasing (Mansourati and Le Grand 1993; Crumb et al. 1995), while that of $\mathrm{I}_{\mathrm{K} 1}$ (Crumb et al. 1995) and $\mathrm{I}_{\mathrm{Ca}-\mathrm{L}}$ (Cohen and Lederer 1993; Roca et al. 1996) is not changing during the ontogeny of canine and human hearts. The importance of developmental studies on ion channel expression may be verified by the changes of ion current densities observed during electrical remodeling caused by a variety of pathological states. These changes are reciprocal to those seen during the ontogeny, i.e. the embryonic patterns are reintroduced in the diseased hearts.

\section{Materials and Methods}

Cardiac muscle samples were isolated from the atrial and ventricular myocardium of dogs with different ages. Canine embryonic heart tissues (25-60 days of gestation) were collected after surgical removal of uterus, while adult samples were obtained from 2-3 years old animals euthanized with intravenous ketamine hydrochlorid (Calypsolvet $10 \mathrm{mg} \cdot \mathrm{kg}^{-1}$ ) and xylazine hydrochlorid (CPxylazin $\left.1 \mathrm{mg} \cdot \mathrm{kg}^{-1}\right)$. The entire investigation was carried out in accordance with the EU (86/609/EEC) guidelines, and was approved by the local ethical committee.

After the tissue samples were removed from the appropriate part of the heart, they were fast-frozen in liquid nitrogen and stored at $-80^{\circ} \mathrm{C}$. Total RNA was isolated from the tissues using RNeasy Plus Mini Kit (Qiagen, Crawley, UK) according to the manufacturer instructions, then RNA concentration of each sample was measured on a NanoDrop 2000 spectrophotometer (Thermo Fisher Scientific Inc., Wilmington, USA) at a wavelength of $260 \mathrm{~nm}$. Competitive reverse transcription (RT)-polymerase chain reaction (PCR) was used to quantify mRNA expression of the various pore forming and regulatory ion channel proteins. First-strand cDNA was synthesized by RT with canine cardiac RNA samples and oligo(dT) ${ }_{15}$ primer (Promega, Madison, USA) using Omniscript RT Kit (Qiagen, Crawley, UK).

The integrity of each cDNA sample was confirmed by PCR for a general mammalian protein of glucose aldehid phosphate dehydrogenase $(\mathrm{GAPDH}) .50 \mu \mathrm{l}$ reaction volume contained the followings (in $\mu \mathrm{l}$ ): cDNA: 1, PCR buffer $(5 \mathrm{x})$ : 10 , dNTP Mix $\left(10 \mathrm{mmol} \cdot \mathrm{l}^{-1}\right): 1$, primer complex $\left(50 \mu \mathrm{mol} \cdot \mathrm{l}^{-1}\right): 1$, which included both the forward (5AATGAGCCCCAGCCTTCTCCAT) as well as the reverse (5'AAGGTCGGAGTCAACGGATTTGG) primer, Taq polimerase: 0.25 , and nuclease-free water: 36.75 . The reaction

Table 1. Parameters of the polymerase chain reactions specific to various ion channels

\begin{tabular}{|c|c|c|c|c|}
\hline $\begin{array}{l}\text { Ion channel } \\
\text { proteins }\end{array}$ & $\begin{array}{c}\text { Annealing } \\
\text { temperature }\left({ }^{\circ} \mathrm{C}\right)\end{array}$ & $\begin{array}{l}\text { Product } \\
\text { size (bp) }\end{array}$ & Sequences of the primers & Reference \\
\hline Kv1.4 & 53 & 522 & $\begin{array}{l}\text { Sense: ATCATTCGTCTGGTCCGAGTATTC } \\
\text { Antisense: AACTCCTTCTTCCATCTCTAG }\end{array}$ & Han et al. 2002 \\
\hline $\mathrm{Kv} 4.3$ & 54 & 212 & $\begin{array}{l}\text { Sense: TAGATGAGCAGATGTTTGAGC } \\
\text { Antisense: ACTGCCCTGGATGTGGATG }\end{array}$ & Han et al. 2002 \\
\hline KChip2 & $55.5(4 \times)+53.5(31 \times)$ & 239 & $\begin{array}{l}\text { Sense: GAGGACTTTGTGGCTGG } \\
\text { Antisense: CCATCCTTGTTTCTGTCC }\end{array}$ & Han et al. 2002 \\
\hline Kv1.5 & $58(4 \times)+56(31 \times)$ & 429 & $\begin{array}{l}\text { Sense: GGCTGACAACCAGGAGACCCA } \\
\text { Antisense: GATCGCCGCAAGTCCACATT }\end{array}$ & * \\
\hline Kir2.1 & 56 & 393 & $\begin{array}{l}\text { Sense: GACCTGGAGACGGACGAC } \\
\text { Antisense: AGCCTGGAGTCTGTCAAAGTC }\end{array}$ & Yue et al. 1999 \\
\hline HERG & $58(4 \times)+56(31 \times)$ & 311 & $\begin{array}{l}\text { Sense: ACGGCGCTCTACTTCACC } \\
\text { Antisense: ACCGCGTTCATGTCGATG }\end{array}$ & Yue et al. 1999 \\
\hline KvLQT1 & 56 & 260 & $\begin{array}{l}\text { Sense: GTCTACAACTTCCTCGAGCGTCCC } \\
\text { Antisense: TTCCGGGCAAAGCGCAGC }\end{array}$ & Han et al. 2002 \\
\hline $\min \mathrm{K}$ & 53.5 & 179 & $\begin{array}{l}\text { Sense: CTACATCCGCTCCAAGAAG } \\
\text { Antisense: CAGGAAGGTGTGTGTTGG }\end{array}$ & Han et al. 2002 \\
\hline Nav1.5 & $54(5 \times)+52(30 \times)$ & 314 & $\begin{array}{l}\text { Sense: TGCATTAACCAGACAGAGG } \\
\text { Antisense: CCAATAAAGAGGTTCAGGGTG }\end{array}$ & Yue et al. 1999 \\
\hline Cav1.2 & 53 & 269 & $\begin{array}{l}\text { Sense: CAATGACACGATCTTCACC } \\
\text { Antisense: GGATGCCAAAGGAGATG }\end{array}$ & Han et al. 2002 \\
\hline Cav3.2 & 52.5 & 334 & $\begin{array}{l}\text { Sense: CTCCTTCCTGCTCATCG } \\
\text { Antisense: GTTGCAGTACTTGAGGGC }\end{array}$ & Han et al. 2002 \\
\hline
\end{tabular}

* primers were designed by PREMIER Biosoft International; bp, basepairs. 
mixture was denatured (at $94^{\circ} \mathrm{C}$ for 3 minutes) and subjected to $35 \mathrm{PCR}$ cycles (denaturation $\left(94^{\circ} \mathrm{C}, 30 \mathrm{~s}\right)$, annealing $\left(56^{\circ} \mathrm{C}\right.$, $45 \mathrm{~s})$, and elongation $\left(72^{\circ} \mathrm{C}, 60 \mathrm{~s}\right)$ ) followed by a final extension period of $7 \mathrm{~min}$ at $72^{\circ} \mathrm{C}$. All these PCR reactions were carried out using Taq polymerase (Promega). Composition of the reaction volume and the main temperature settings were the same in the gene specific PCR reactions except for the annealing temperature, which was individually determined for each primer pairs (all from Bio-Science, Budapest, Hungary). Parameters of the polymerase chain reactions for each ion channel protein are summarized in Table 1. Absence of genomic contamination of RNA samples was confirmed with reverse transcriptase-negative controls in each experiment.

Electrophoresis of the amplified products was performed on $1.5 \%$ agarose gels containing (in $\mathrm{mmol} / \mathrm{l}$ ): TRIS 100 , boric acid $100, \mathrm{Na}_{2}$ EDTA 2 , and ethidium bromide. Ethidium bromide fluorescence images were captured using a camera (Kodak Gel Logic 1500 Imaging System, Carestream Health Inc., Rochester, USA) under ultraviolet light. The density of each band was determined using Image-Pro Plus software (Media Cybernetics Inc., Bethesda, USA). Each data from densitometry was normalized to density of the appropriate GAPDH-band. Data were then organized and processed using Microsoft Excel, PowerPoint, and Microcal Origin 6.0 softwares.

Comparisons were made between heart samples obtained from embryonic and adult dogs. From each heart, atrial and ventricular tissues were excised separately and compared to evaluate atrio-ventricular differences in both embryonic and adult hearts. The adult ventricular samples represented the full cross-section of the ventricular wall containing a natural mixture of epicardial, endocardial and (dominantly) midmyocardial tissues. Equal amounts of tissues, dissected from the left and right respective chamber of the heart, were pooled together to exclude distortions due to possible left-right differences. Results are expressed as mean \pm SEM values. Statistical significance of differences was evaluated with one-way ANOVA followed by Student's t-test for unpaired data. Differences were considered significant when $p$ was less than 0.05 .

\section{Results}

Since in the followings, the expression level of each ion channel mRNA will be normalized to that of the housekeeping protein, GAPDH obtained from the same tissue sample, first the age- and tissue-dependent pattern of expression of GAPDH mRNA has to be demonstrated. As indicated in Fig. 1, neither significant atrio-ventricular differences, nor age-dependent changes could be observed. This result is important to verify our analysis based on comparison of ion channel mRNA data normalized to GAPDH mRNA obtained from the same tissue sample.

Transient outward $\mathrm{K}^{+}$current $\left(\mathrm{I}_{\mathrm{to}}\right)$ density in the canine heart is determined by two pore forming subunits, Kv4.3
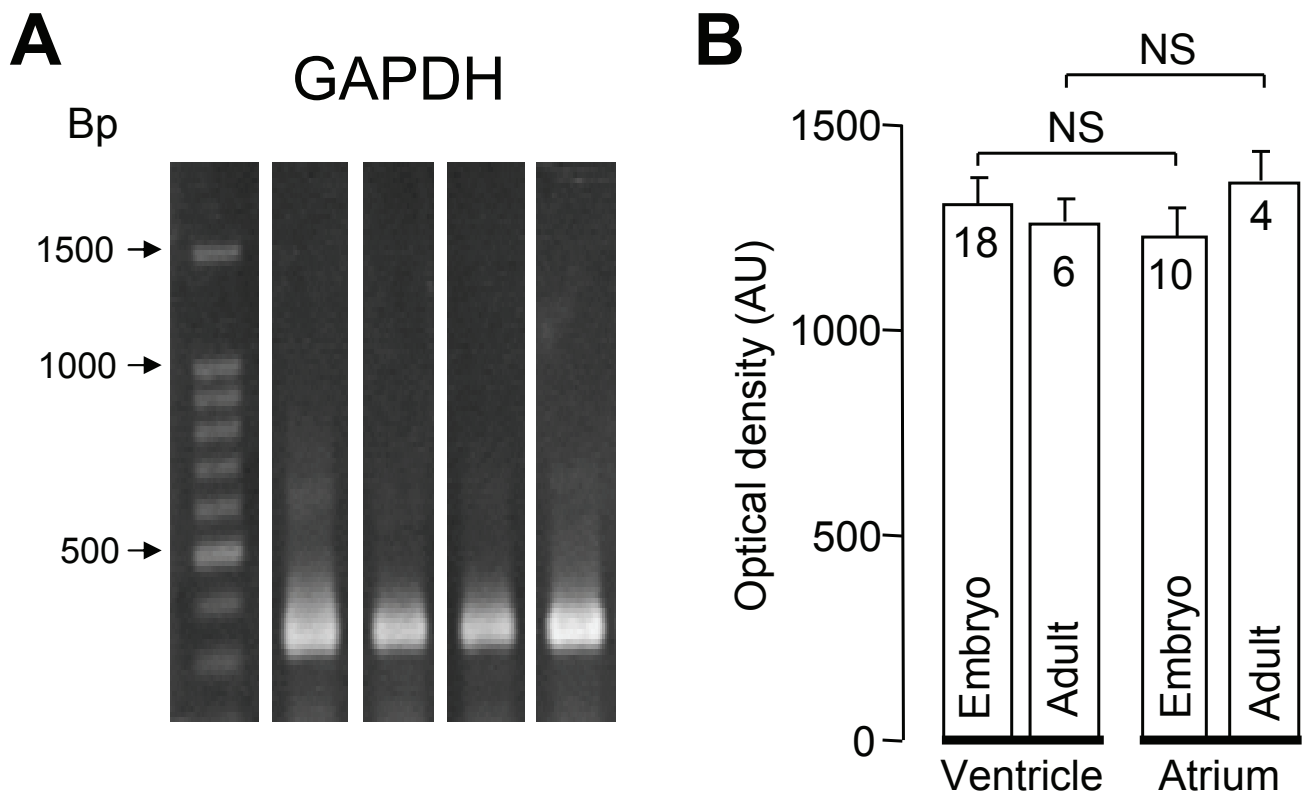

Figure 1. Representative densitogram (A) and average data (B) indicating the expression level of the housekeeping protein, GAPDH mRNA in embryonal and adult canine atrial and ventricular myocardium. Numbers within the columns indicate the number of samples. Calibration (arrows at left) denotes base pairs (Bp). NS, not significant. 
and $\mathrm{Kv1.4}$ (the former being dominant), plus an auxiliary subunit, KChIP2. As demonstrated in Fig. 2A-C, all mRNAs coding these proteins are more abundant in adult than in embryonic myocardium, regardless of the atrial or ventricular origin of the tissues. Comparing the atrial and ventricular samples, Kv4.3 mRNA level was higher in the ventricles than in the atria (in both embryonic and adult tissues), no atrio-ventricular difference was found in the Kv1.4 mRNA level, while KChIP2 density was higher in atrial than ventricular myocardium of the embryonic hearts, in contrast to adult tissues, where this difference was dissipated during the ontogeny.

The delayed rectifier $\mathrm{K}^{+}$current family was represented by three independent $\mathrm{K}^{+}$currents, namely the rapid delayed rectifier $\left(\mathrm{I}_{\mathrm{Kr}}\right)$, the slow delayed rectifier $\left(\mathrm{I}_{\mathrm{Ks}}\right)$, and the ultra-rapid component $\left(\mathrm{I}_{\mathrm{Kur}}\right)$, with the respective pore forming subunits of HERG, KvLQT1, and Kv1.5. In addition, the auxiliary subunit, minK, is also involved in tuning the density and kinetic properties of $\mathrm{I}_{\mathrm{Ks}}$. HERG coding mRNA density showed neither age-dependent changes, nor atrio-ventricular differences (Fig. 3A). Reciprocal age-dependent changes were observed when comparing the density of mRNAs coding for KvLQT1 and $\operatorname{minK}$, as the former increased, while the latter decreased with ontogeny in both atrial and ventricular myocardium, without showing any atrio-ventricular difference (Fig. $3 \mathrm{~B}, \mathrm{C})$. In contrast, no age-dependent variation was found in the case of Kv1.5 mRNA, but its density was higher in the ventricles than in the atria, independently of its embryonic or adult origin (Fig. 3D). The inward rectifier $\mathrm{K}^{+}$ current $\left(\mathrm{I}_{\mathrm{K} 1}\right)$ is mediated dominantly by Kir2.1 channel protein. Its mRNA level was not altered significantly by the age of the animal, or by the atrio-ventricular origin of the sample (Fig. 3E).
A
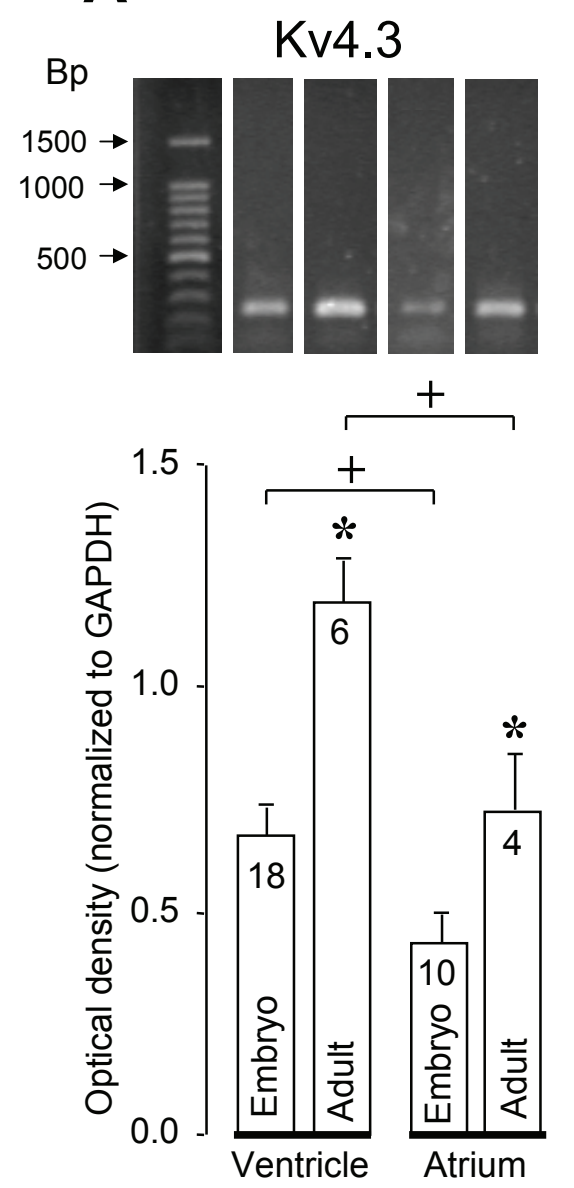

B
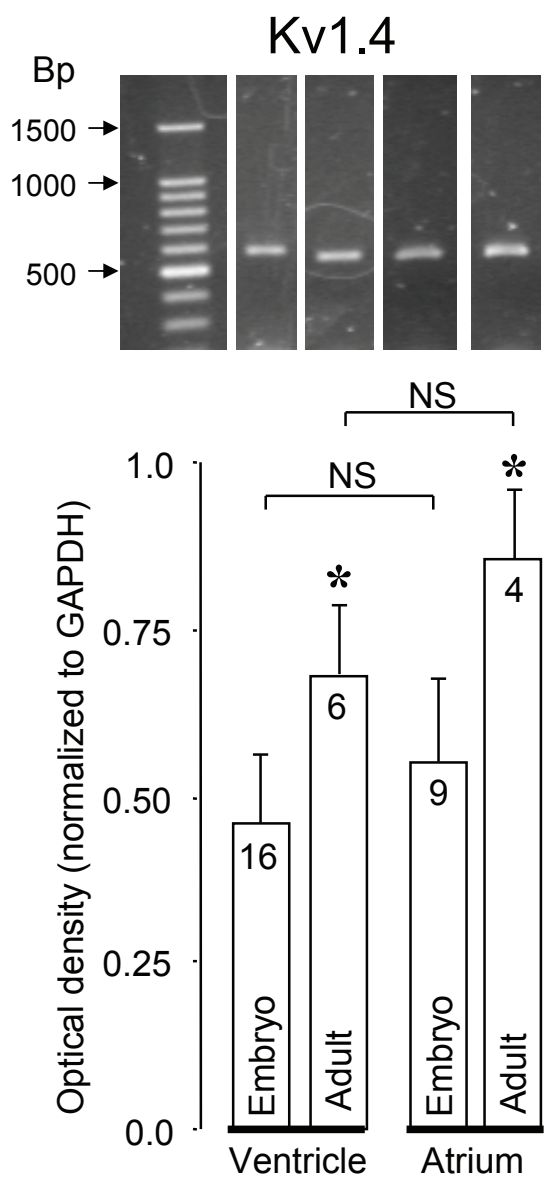
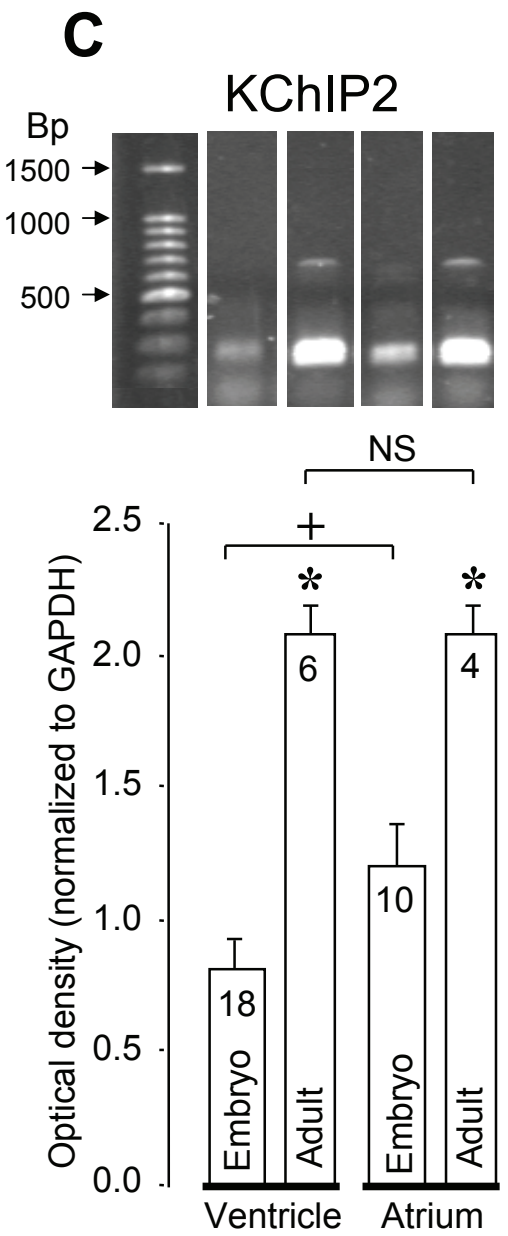

Figure 2. Age-related and atrio-ventricular differences in the mRNA level coding for ion channel proteins related to $\mathrm{I}_{\text {to }}$ in canine cardiac tissues: Kv4.3 (A), Kv1.4 (B), KChIP2 (C). Representative densitograms are presented in the upper panels, while lower panels show the corresponding average data. ${ }^{*}$ significant age-related differences, $p<0.05$; + significant atrio-ventricular differences, $p<0.05$; NS, not significant. 

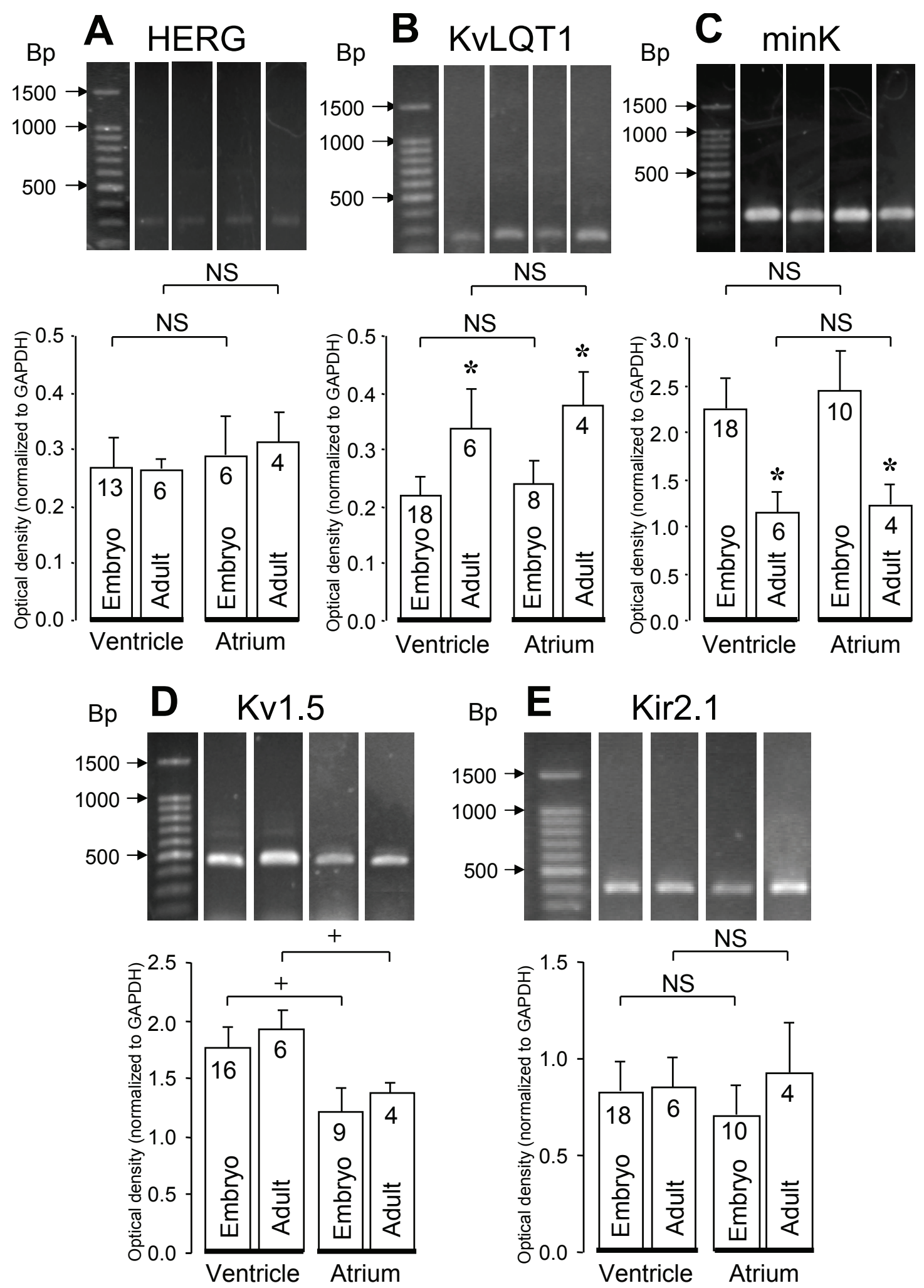

Figure 3. Age-related and atrio-ventricular differences in the mRNA level coding for ion channel proteins related to cardiac delayed rectifier HERG (A), KvLQT1 (B), minK (C), Kv1.5 (D) and inward rectifier currents Kir2.1 (E). Densitograms and the corresponding average data are presented in the upper and lower panels, respectively. ${ }^{*}$ significant age-related differences, $p<0.05$; + significant atrioventricular differences, $p<0.05$; NS, not significant. 
Age-dependent variability of three pore forming channel subunits, each carrying inward current, was also examined. Fast $\mathrm{Na}^{+}$current $\left(\mathrm{I}_{\mathrm{Na}}\right)$, responsible for the upstroke of the action potential, is mediated chiefly by Nav1.5 protein in the canine heart. Nav1.5 mRNA expression level drastically decreased with ontogeny in both atrial and ventricular myocardium (Fig. 4A). Interestingly, embryonic atria contained more Nav1.5 RNA than the age-matched ventricles, while the opposite distribution was observed in the adult hearts (i.e. more RNA was expressed in adult ventricles than in adult atria). Neither age-related, nor atrio-ventricular differences were explored in case of Cav1.2 mRNA, coding for the pore forming subunit of L-type $\mathrm{Ca}^{2+}$ channels ( $\mathrm{I}_{\mathrm{Ca}-\mathrm{L}}$, Fig. 4B). On the other hand, significant age-related elevation in the expression level of Cav3.2 mRNA, coding for the pore forming subunit of T-type $\mathrm{Ca}^{2+}$ channels
$\left(\mathrm{I}_{\mathrm{Ca}-\mathrm{T}}\right)$ was observed, without showing atrio-ventricular differences (Fig. 4C).

\section{Discussion}

\section{Comparison of present results to human and canine data from the literature}

In our experiments, mRNAs coding for ion channel proteins related to $\mathrm{I}_{\text {to }}$ (i.e. Kv4.3, Kv1.4, and KChIP2) were uniformly higher in adult than in the embryonic canine samples. These results agree well with those of others studying developmental changes in the density of canine $\mathrm{I}_{\text {to }}$ (Jeck and Boyden 1992; Pacioretti and Gilmour 1995) or the underlying channel proteins (Plotnikov et al. 2004). They are also in line with

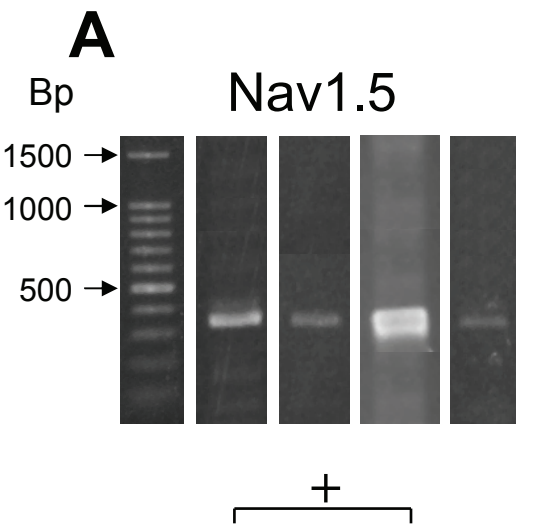

\section{B}
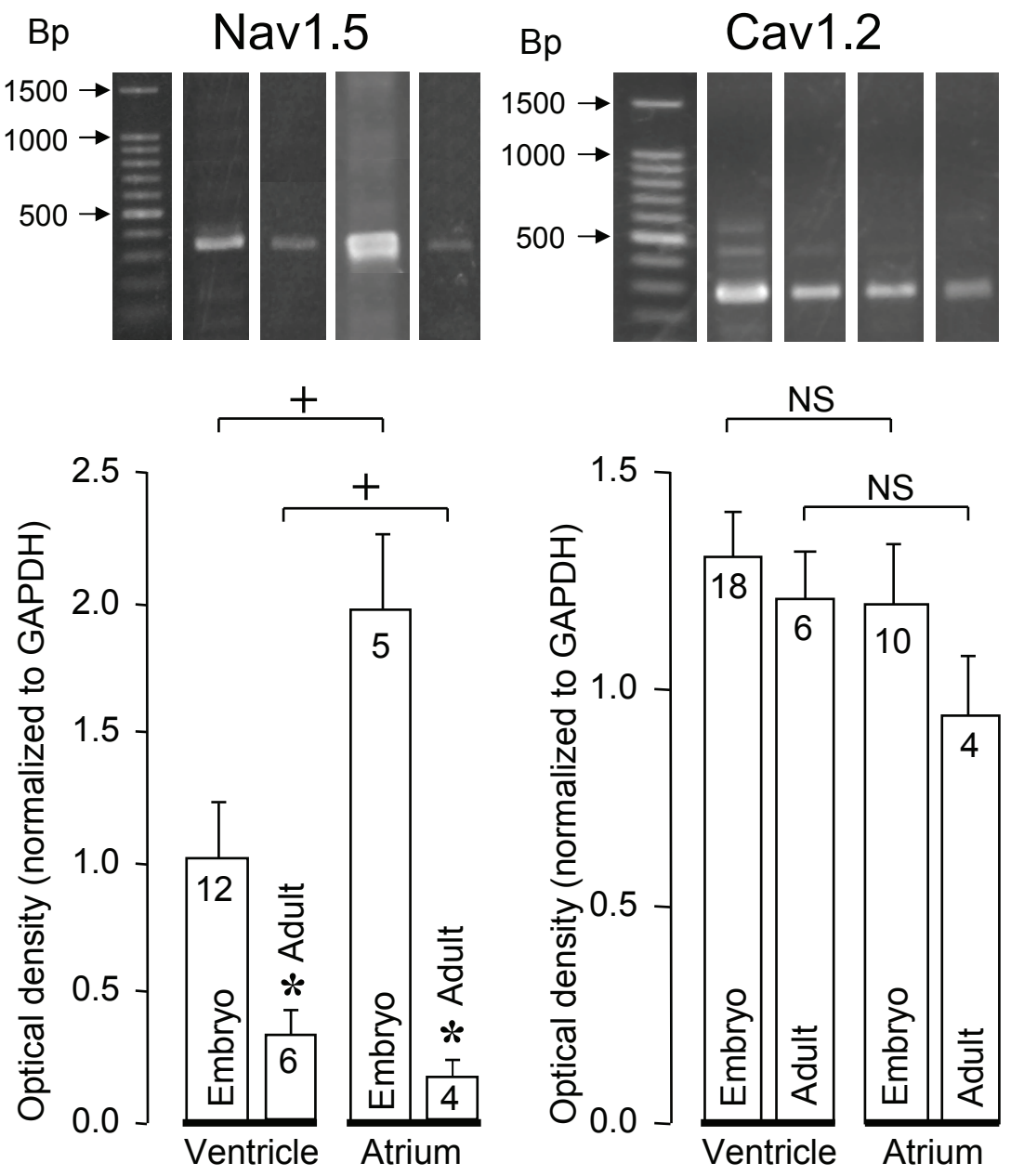

Cav3.2

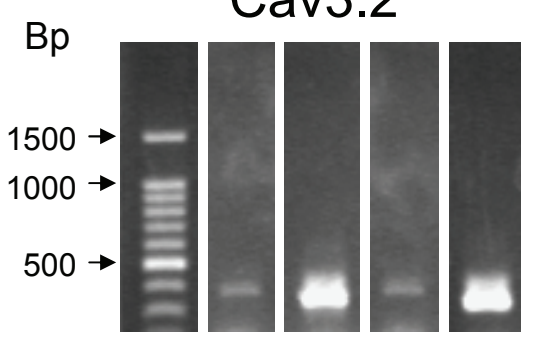

NS

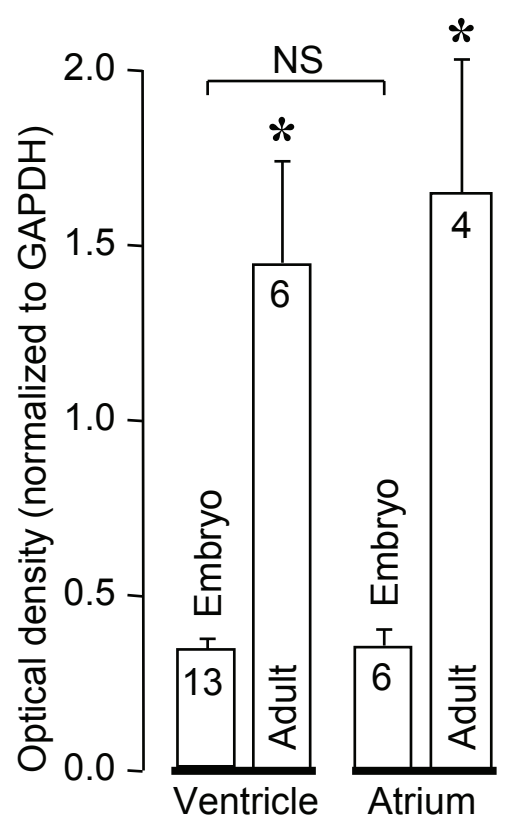

Figure 4. Age-related and atrio-ventricular differences in the mRNA level coding for ion channel proteins mediating inward currents Nav1.5 (A), Cav1.2 (B), Cav3.2 (C). Densitograms with the corresponding average data are shown in the upper and lower panels, respectively. ${ }^{*}$ significant age-related differences, $p<0.05$; + significant atrio-ventricular differences, $p<0.05$; NS, not significant. 
relevant human data on $\mathrm{I}_{\mathrm{to}}$, showing marked increase of the current during ontogeny (Mansourati and Le Grand 1993; Crumb et al. 1995). Similar results were obtained with $\mathrm{I}_{\text {to }}$ in aging human stem cells (Sartiani et al. 2007).

Regarding the rapid and slow components of the delayed rectifier $\mathrm{K}^{+}$current, the density of $\mathrm{I}_{\mathrm{Kr}}$ decreased, while $\mathrm{I}_{\mathrm{Ks}}$ increased during the postnatal period of dogs (Obreztchikova et al. 2003; Krishnamurthy et al. 2004). These changes in current densities were accompanied with reduction of HERG, increase in minK, and no change in KvLQT1 expression at both mRNA and protein levels (Krishnamurthy et al. 2004). Although these alterations are not identical with the present results, since we observed an increase in KvLQT1, reduction of minK, and no change in HERG expression, however, they are not exclusive at all. In the above mentioned studies only postnatal alterations were monitored (neonates versus adults), while the possible prenatal changes were neglected. This may explain the differences seen between our results and those of Obreztchikova et al. (2003) and Krishnamurthy et al. (2004). No relevant human data on $\mathrm{I}_{\mathrm{Kr}}$ or $\mathrm{I}_{\mathrm{Ks}}$ is available for comparison.

We observed no developmental changes in the expression levels of Kir2.1 mRNA, mediating $\mathrm{I}_{\mathrm{K} 1}$, Cav1.2 mRNA, responsible for $\mathrm{I}_{\mathrm{Ca}-\mathrm{L}}$, and in $\mathrm{Kv} 1.5$ mRNA coding for the ultra-rapid component of $\mathrm{I}_{\mathrm{K}}$, denoted as $\mathrm{I}_{\mathrm{Kur}}$. In a good accordance with our results, no change in the density of $\mathrm{I}_{\mathrm{K} 1}$ (Crumb et al. 1995) and $\mathrm{I}_{\mathrm{Ca}-\mathrm{L}}$ (Cohen and Lederer 1993; Roca et al. 1996) were observed during the ontogeny of human myocardium. Although in a recent human study lower density of baseline $\mathrm{I}_{\mathrm{Ca}-\mathrm{L}}$ was measured in the atrial myocardium of infants than that of adults, this difference disappeared in the presence of isoproterenol resulting full activation of the current (Tipparaju et al. 2004). Regarding $\mathrm{I}_{\text {Kur }}$ this current is abundantly expressed in 8-10 weeks fetal human hearts, however, no comparison to adults is available (Bielanska et al. 2010).

\section{Comparison of present results to those obtained in other mammalian species}

Apart from $\mathrm{I}_{\text {to }}$ and the related channel proteins, which are clearly increasing throughout the various stages of ontogeny in all mammalian species, including dogs (Jeck and Boyden 1992; Pacioretti and Gilmour 1995; Plotnikov et al. 2004), humans (Mansourati and Le Grand 1993; Crumb et al. 1995), rabbits (Sanchez-Chapula et al. 1994; Elizalde et al. 1999), rats (Guo et al. 1997a,b), and mice (Wang and Duff 1997; Harrell et al. 2007), there are unusually extensive interspecies differences regarding the other channel/current systems. For instance, $\mathrm{I}_{\mathrm{K} 1} / \mathrm{Kir} 2.1$ was not found to be age-dependent in dogs (present study), humans (Crumb et al. 1995), and guinea pigs (Kato et al. 1996), while its amplitude was shown to increase with age in rabbits (Chen et al. 1991; Huynh et al.
1992), rats (Wahler 1992; Nagashima et al. 2001), and mice (Davies et al. 1996; Grandy et al. 2007).

The pattern of age-related changes is not less conflicting in the case of the three delayed rectifier $\mathrm{K}^{+}$currents: $\mathrm{I}_{\mathrm{Kr}} \mathrm{I}_{\mathrm{Ks}}$, and $\mathrm{I}_{\mathrm{Kur}}$. The density of $\mathrm{I}_{\mathrm{Kr}}$ increased with ontogeny in guinea pigs (Kato et al. 1996), but decreased in mice (Wang et al. 1996, 2000). Expression of HERG mRNA was comparable in embryonic and adult canine hearts (present study), although it was shown to decrease during the postnatal period (Krishnamurthy et al. 2004). $\mathrm{I}_{\mathrm{Ks}}$ density increased during the ontogeny in guinea pigs (Kato et al. 1996), dogs (Obreztchikova et al. 2003), and mice (Wang et al. 1996; Grandy et al. 2007). The increment of $\mathrm{I}_{\mathrm{Ks}}$ density, however, this could either be associated with an age-dependent reduction (Harrell et al. 2007; present study) or elevation (Krishnamurthy et al. 2004) of the expression level of $\operatorname{minK}$, and also with an unchanged (Krishnamurthy et al. 2004; Trépanier-Boulay et al. 2004) or increased (present study) density of KvLQT1.

Expression of Kv1.5, responsible for $\mathrm{I}_{\mathrm{Kur}}$ increased during the ontogeny in mice (Harrell et al. 2007), decreased in rats (Guo et al. 1997b), while was not age-dependent in dogs (present study). Accordingly, the density of $\mathrm{I}_{\mathrm{Kur}}$ increased in mice (Grandy et al. 2007) and decreased in rats (Guo et al. 1997a,b) with age.

Regarding inward currents, expression of Cav1.2, the pore forming subunit of $\mathrm{I}_{\mathrm{Ca}-\mathrm{L}}$, together with the corresponding current density, increased with ontogeny in rabbits (Wetzel et al. 1991, 1993; Osaka and Joyner 1991; Huang et al. 2006; Namiki et al. 2007), guinea pigs (Kato et al. 1996), and mice (Davies et al. 1996; Liu et al. 2002; Harrell et al. 2007; Nguemo et al. 2009), decreased in rats (Cohen and Lederer 1988), while was not age-dependent in humans (Cohen and Lederer 1993; Roca et al. 1996), and dogs (present study). $\mathrm{I}_{\mathrm{Ca}-\mathrm{T}}$ density and Cav3.2 expression was shown to increase with age in rabbits (Wetzel et al. 1991) and dogs (present study), decrease in mice (Yasui et al. 2005; Harrell et al. 2007), while displayed a biphasic change by first increasing then decreasing in rat atrial myocytes (Xu and Best 1992). $\mathrm{I}_{\mathrm{Na}}$ density increased with ontogeny in mice (Davies et al. 1996; Harrell et al. 2007). In dogs, Nav1.5 mRNA expression decreased with aging (present study), while expression of Nav1.5 at both mRNA and protein levels displayed a biphasic change by first decreasing then increasing in the sheep (Fahmi et al. 2004).

\section{Atrio-ventricular differences}

Direction of the developmental change in the mRNA level, determined for any specific channel protein, was always identical in the atrial and ventricular samples. Comparison of atrial and ventricular mRNAs in the adult samples revealed that for Kv4.3, Kv1.5, and Nav1.5, the expression was lower in the atrial than ventricular tissues. No atrio-ventricular 
differences in the mRNA content were found in the case of Kv1.4, KChIP2, HERG, KvLQT1, minK, Kir2.1, Cav1.2, and Cav3.2. Regarding embryonic tissues, atrial expression was higher than ventricular for KChIP2 and Nav1.5. Some of these atrio-ventricular differences (in the expression of Kv1.4, KChIP2, HERG, KvLQT1, minK, Cav1.2, and Nav1.5) are similar in adult canine and human cardiac muscle preparations, while marked differences (in Kv4.3, Kv1.5, Kir2.1, and Cav3.2) were also found (Ördög et al. 2006; Gaborit et al. 2007). Interestingly, all atrio-ventricular differences found in ion current densities in mice (i.e. stronger $\mathrm{I}_{\text {to }}$ and $\mathrm{I}_{\mathrm{Kur}}$ in ventricles, while no difference in $\mathrm{I}_{\mathrm{K} 1}$; Grandy et al. 2007) were identical to those observed in the distribution of the corresponding mRNA expression in the canine preparations of the present study. The most unexpected and striking difference was found in the case of $\mathrm{I}_{\mathrm{Kur}} / \mathrm{Kv} 1.5$, since it was abundantly localized in the atria of human myocardium, while dominantly in the ventricles of dogs and mice.

In summary, our canine mRNA results are largely congruent with human voltage clamp data, indicating that the density of $\mathrm{I}_{\text {to }}$ and $\mathrm{I}_{\mathrm{Ks}}$ is increasing, while that of $\mathrm{I}_{\mathrm{K} 1}$ and $\mathrm{I}_{\mathrm{Ca}-\mathrm{L}}$ is not changing during ontogeny in these species. The age-dependent increase observed in the expression of Kv4.3, $\mathrm{Kv} 1.4, \mathrm{KChIP} 2$, and KvLQT1 is congruent with the greater repolarization reserve of the adult myocardium, associated with higher densities of $\mathrm{I}_{\text {to }}$ and $\mathrm{I}_{\mathrm{Ks}}$, respectively. Based on the present results one may anticipate, that age-dependent changes in the expression pattern of ion channels are similar in canine and healthy human myocardium. Taking into account the extremely wide interspecies variability among the other mammalian species in this regard, the canine cardiac muscle samples can be considered as good models for studying developmental changes in the human heart.

Acknowledgements. Financial support for the studies was provided by grants from the Hungarian Research Fund (OTKA-K68457, OTKA-K73160, CNK-77855), and the Hungarian Government (TáMOP-4.2.1/B-09/1/KONV-2010-007). The authors thank Mrs. Vighné Katalin Horváth for excellent technical assistance.

\section{References}

Bielanska J., Hernández-Losa J., Moline T., Somoza R., Ramón Y Cajal S., Condom E., Ferreres J. C., Felipe A. (2010): Voltagedependent potassium channels Kv1.3 and Kv1.5 in human fetus. Cell. Physiol. Biochem. 26, 219-226 http://dx.doi.org/10.1159/000320528

Chen F., Wetzel G. T., Friedman W. F., Klitzner T. S. (1991): Single channel recording of inwardly rectifying potassium currents in developing myocardium. J. Mol. Cell. Cardiol. 23, 259-267 http://dx.doi.org/10.1016/0022-2828(91)90062-Q

Cohen N. M., Lederer W. J. (1988): Changes in calcium current of rat heart ventricular myocytes during development. J. Physiol. (London) 406, 115-146
Cohen N. M., Lederer W. J. (1993): Calcium current in single human cardiac myocytes. J. Cardiovasc. Electrophysiol. 4, 422-437 http://dx.doi.org/10.1111/j.1540-8167.1993.tb01281.x

Crumb W. J., Pigott J. D., Clarkson C. W. (1995): Comparison of Ito in young and adult human atrial myocytes: evidence for developmental changes. Am. J. Physiol. 268, H1335-1342

Davies M. P., An R. H., Doevendans P., Kubalak S., Chien K. R., Kass R. S. (1996): Developmental changes in ionic channel activity in the embryonic murine heart. Circ. Res. 78, 15-25

Elizalde A., Barajas H., Navarro-Polanco R., Sanchez-Chapula J. (1999): Frequency-dependent effects of 4-aminopyridine and almokalant on action-potential duration of adult and neonatal rabbit ventricular muscle. J. Cardiovasc. Pharmacol. 33, 352-359 http://dx.doi.org/10.1097/00005344-199903000-00002

Fahmi A. I., Forhead A. J., Fowden A. L., Vandenberg J. I. (2004): Cortisol influences the ontogeny of both alpha- and beta-subunits of the cardiac sodium channel in fetal sheep. J. Endocrinol. 180, 449-455 http://dx.doi.org/10.1677/joe.0.1800449

Fujii S., Ayer R. K., DeHaan R. L. (1986): Differentiation of transmembrane ionic currents in the early embryonic chick heart. Prog. Clin. Biol. Res. (part A) 217, 353-356

Gaborit N., Le Bouter S., Szuts V., Varro A., Escande D., Nattel S., Demolombe S. (2007): Regional and tissue specific transcript signatures of ion channel genes in the non-diseased human heart. J. Physiol. (London) 582, 675-693 http://dx.doi.org/10.1113/jphysiol.2006.126714

Grandy S. A., Trépanier-Boulay V., Fiset C. (2007): Postnatal development has a marked effect on ventricular repolarization in mice. Am. J. Physiol. 293, H2168-2177

Guo W., Kamiya K., Liu W., Toyama J. (1997a): Developmental changes of the ultrarapid delayed rectifier $\mathrm{K}+$ current in rat ventricular myocytes. Pflügers Arch. 433, 442-445 http://dx.doi.org/10.1007/s004240050298

Guo W., Kamiya K., Toyama J. (1997b): Roles of the voltage-gated $\mathrm{K}+$ channel subunits, Kv1.5, and Kv1.4 in the developmental changes of $\mathrm{K}+$ currents in cultured neonatal rat ventricular cells. Pflügers Arch. 434, 206-208 http://dx.doi.org/10.1007/s004240050385

Han W., Bao W., Wang Z., Nattel S. (2002): Comparison of ionchannel subunit expression in canine cardiac Purkinje fibers and ventricular muscle. Circ. Res. 91, 790-797 http://dx.doi.org/10.1161/01.RES.0000039534.18114.D9

Harrell M. D., Harbi S., Hoffman J. F., Zavadil J., Coetzee W. A. (2007): Large-scale analysis of ion channel gene expression in the mouse heart during perinatal development. Physiol. Genomics 28, 273-283 http://dx.doi.org/10.1152/physiolgenomics.00163.2006

Huang J., Xu L., Thomas M., Whitaker K., Hove-Madsen L., Tibbits G. F. (2006): L-type Ca2+ channel function and expression in neonatal rabbit ventricular myocytes. Am. J. Physiol. 290, H2267-2276

Huynh T. V., Chen F., Wetzel G. T., Friedman W. F., Klitzner T. S. (1992): Developmental changes in membrane Ca2+ and K+ currents in fetal, neonatal, and adult rabbit ventricular myocytes. Circ. Res. 70, 508-515 
Jeck C. D., Boyden P. A. (1992): Age-related appearance of outward currents may contribute to developmental differences in ventricular repolarization. Circ. Res. 71, 1390-1403

Jezek K., Pucelik P., Sauer J., Barták F. (1982): Basic electrophysiological parameters and frequency-sensitivity of the ventricular myocardium of human embryos. Physiol. Bohemoslov. 31, 11-19

Jezek K., Pucelik P., Sauer J., Barták F. (1984): Effect of acetylcholine and adrenaline on ventricular action potentials of the human embryonic myocardium. Physiol. Bohemoslov. 33, 463-469

Jezek K., Knaizl Z., Králicek P., Pucelik P., Sauer J. (1985): Effect of a pause on action potentials of the working ventricular myocardium of human embryos. Physiol. Bohemoslov. 34, 69-76

Kato Y., Masumiya H., Agata N., Tanaka H., Shigenobu K. (1996): Developmental changes in action potential and membrane currents in fetal, neonatal and adult guinea-pig ventricular myocytes. J. Mol. Cell. Cardiol. 28, 1515-1522 http://dx.doi.org/10.1006/jmcc.1996.0141

Krishnamurthy G., Patberg K. W., Obreztchikova M. N., Rybin A. V., Rosen M. R. (2004) Developmental evolution of the delayed rectifier current IKs in canine heart appears dependent on the beta subunit min K. Heart Rhythm 1, 704-711 http://dx.doi.org/10.1016/j.hrthm.2004.08.012

Liu W., Yasui K., Opthof T., Ishiki R., Lee J. K., Kamiya K., Yokota M., Kodama I. (2002) Developmental changes of Ca2+ handling in mouse ventricular cells from early embryo to adulthood. Life Sci. 71, 1279-1292 http://dx.doi.org/10.1016/S0024-3205(02)01826-X

Mansourati J., Le Grand B. (1993): Transient outward current in joung and adult diseased human atria. Am. J. Physiol. 265, H1466-1470

Nagashima M., Tohse N., Kimura K., Yamada Y., Fujii N., Yabu H. (2001): Alternation of inwardly rectifying background K+ channel during development of rat fetal cardiomyocytes. J. Mol. Cell. Cardiol. 33, 533-543 http://dx.doi.org/10.1006/jmcc.2000.1327

Namiki T., Joyner R. W., Wagner M. B. (2007): Developmental changes in time course of recovery from inactivation in L-type calcium currents of rabbit ventricular myocytes. Am. J. Physiol. 292, H295-303

Nguemo F., Sasse P., Fleischmann B. K., Kamanyi A., Schunkert H., Hescheler J., Reppel M. (2009): Modulation of L-type Ca2+ channel current density and inactivation by beta-adrenergic stimulation during murine cardiac embryogenesis. Basic Res. Cardiol. 104, 295-306 http://dx.doi.org/10.1007/s00395-008-0755-7

Obreztchikova M. N., Sosunov E. A., Plotnikov A., Anyukhovsky E. P., Gainullin R. Z., Danilo P., Yeom Z. H., Robinson R. B., Rosen M. R. (2003): Developmental changes in IKr and IKs contribute to age-related expression of dofetilide effects on repolarization and proarrhythmia. Cardiovasc. Res. 59, 339-350 http://dx.doi.org/10.1016/S0008-6363(03)00360-2

Ördög B., Brutyó E., Puskás L. G., Papp J. Gy., Varró A., Szabad J., Boldogkôi Z. (2006): Gene expression profiling of human cardiac potassium and sodium channels. Int. J. Cardiol. 111, 386-393 http://dx.doi.org/10.1016/j.ijcard.2005.07.063

Osaka T., Joyner R. W. (1991): Developmental changes in calcium currents of rabbit ventricular cells. Circ. Res. 68, 788-796
Pacioretti L. M., Gilmour R. F. (1995): Developmental changes of action potential configuration and Ito in canine epicardium. Am. J. Physiol. 268, H2513-2521

Plotnikov A. N., Sosunov E. A., Patberg K. W., Anyukhovsky E. P., Gainullin R. Z., Shlapakova I. N., Krishnamurthy G., Danilo P., Rosen M. (2004): Cardiac memory evolves with the age in association with development of the transient outward current. Circulation 110, 489-495 http://dx.doi.org/10.1161/01.CIR.0000137823.64947.52

Roca T. P., Pigott J. D., Clarkson C. W., Crumb W. J. (1996): L-type calcium current in pediatric and adult human atrial myocytes: evidence for developmental changes in channel inactivation. Pediatric Res. 40, 462-468 http://dx.doi.org/10.1203/00006450-199609000-00016

Sada H., Ban T., Fujita T., Ebina Y., Sperelakis N. (1995): Developmental change in fast $\mathrm{Na}$ channel properties in embryoinc chick ventricular heart cells. Can. J. Physiol. Pharmacol. 73, 1475-1484 http://dx.doi.org/10.1139/y95-205

Sanchez-Chapula J., Elizalde A., Navarro-Polanco R., Barajas H. (1994): Differences in outward currents between neonatal and adult rabbit ventricular cells. Am. J. Physiol. 266, H1184-1194

Sartiani L., Bettiol E., Stillitano F., Mugelli A., Cerbai E., Jaconi M. E. (2007): Developmental changes in cardiomyocytes differentiated from human embryonic stem cells: a molecular and electrophysiological approach. Stem Cells 25, 1136-1144 http://dx.doi.org/10.1634/stemcells.2006-0466

Sperelakis N. (1989): Developmental changes in membrane electrical properties of the heart. In: Physiology and Pathophysiology of the Heart. (Ed. N. Sperelakis), pp. 595-623, Kluwer Academic Publishers http://dx.doi.org/10.1007/978-1-4613-0873-7_29

Szabó G., Szentandrássy N., Bíró T., Tóth I. B., Czifra G., Magyar J., Bányász T., Varró A., Kovács L., Nánási P. P. (2005): Asymmetrical distribution of ion channels in canine and human left ventricular wall: epicardium versus midmyocardium. Pflügers Arch. 450, 307-316 http://dx.doi.org/10.1007/s00424-005-1445-z

Szentandrássy N., Bányász T., Bíró T., Szabó G., Tóth I. B., Magyar J., Lázár J., Varró A., Kovács L., Nánási P. P. (2005): Apico-basal inhomogeneity in distribution of ion channels in canine and human ventricular myocardium. Cardiovasc. Res. 65, 851-860 http://dx.doi.org/10.1016/j.cardiores.2004.11.022

Tipparaju S. M., Kumar R., Wang Y., Joyner R. W., Wagner M. B. (2004): Developmental differences in L-type calcium current of human atrial myocytes. Am. J. Physiol. 286, H1963-1969

Tohse N., Mészáros J., Sperelakis N. (1992): Developmental changes in long-opening behavior of L-type Ca2+ channels in embryonic chick heart cells. Circ. Res. 71, 376-384

Trépanier-Boulay V., Lupien M. A., St-Michel C., Fiset C. (2004): Postnatal development of atrial repolarization in the mouse. Cardiovasc. Res. 64, 84-93 http://dx.doi.org/10.1016/j.cardiores.2004.06.002

Wahler G. M. (1992): Developmental increases in the inwardly rectifying potassium current of rat ventricular myocytes. Am. J. Physiol. 262, C1266-1272 
Wang L., Feng Z. P., Kondo C. S., Sheldon R. S., Duff H. J. (1996): Developmental changes in the delayed rectifier $\mathrm{K}+$ channels in mouse heart. Circ. Res. 79, 79-85

Wang L., Duff H. J. (1997): Developmental changes in transient outward current in mouse ventricle. Circ. Res. 81, 120-127

Wang L., Swirp S., Duff H. J. (2000): Age-dependent response of the electrocardiogram to $\mathrm{K}+$ channel blockers in mice. Am. J. Physiol. 278, C73-80

Wetzel G. T., Chen F., Klitzner T. S. (1991): L- and T-type calcium channels in acutely isolated neonatal and adult cardiac myocytes. Pediatr. Res. 30, 89-94 http://dx.doi.org/10.1203/00006450-199107000-00018

Wetzel G. T., Chen F., Klitzner T. S. (1993): Ca2+ channel kinetics in acutely isolated fetal, neonatal, and adult rabbit cardiac myocytes. Circ. Res. 72, 1065-1074
Xu X., Best P. M. (1992): Postnatal changes in T-type calcium current density in rat atrial myocytes. J. Physiol. (London) 454, 657-672

Yasui K., Niwa N., Takemura H., Opthof T., Muto T., Horiba M., Shimizu A., Lee J.-K., Honjo H., Kamiya K., Kodama I. (2005): Pathophysiological significance of T-type Ca2+ channels: expression of T-type Ca2+ channels in fetal and diseased heart. J. Pharmacol. Sci. 99, 205-210 http://dx.doi.org/10.1254/jphs.FMJ05002X3

Yue L., Melnyk P., Gaspo R., Wang Z., Nattel S. (1999): Molecular mechanisms underlying ionic remodeling in a dog model of atrial fibrillation. Circ. Res. 84,776-784

Received: September 21, 2011

Final version accepted: February 6, 2012 